\title{
Grazing rates on bacteria: the significance of methodology and ecological factors*
}

\author{
Dolors Vaqué ${ }^{1}$, Josep M. Gasol ${ }^{1,2}$, Cèlia Marrasé ${ }^{1}$ \\ ${ }^{1}$ Institut de Ciències del Mar, CSIC, Passeig Joan de Borbó s/n, E-08039 Barcelona, Spain \\ ${ }^{2}$ Departament de Genètica i de Microbiologia, Universitat Autònoma de Barcelona, E-08193 Bellaterra, Barcelona, Spain
}

\begin{abstract}
Protists and viruses are recognized as the main predators on bacteria in a variety of environments. Several factors may potentially influence the grazing rates of protists on bacteria: temperature, bacterial abundance and production, and protist abundance. We inspected the relative importance of these variables in determining the specific grazing rates of flagellates $(G R F)$, and total community grazing rates (GT) by analyzing a data set extracted from the literature. We included freshwater and marine environments, ranging from oligo- to eutrophic systems. As different methods to measure grazing rates (GRF and $G T$ ) were used by different authors, the data were also analyzed for possible differences among methods. As there were significant differences among certain methods, we classified them into 2 groups: (1) M1 methods, those that measured grazing rates (GRF and GT) through the uptake of fluorescent particles; and (2) M2 methods, those determining community grazing rates (GT) by dilution, inhibition, filtration, or the uptake of genetically marked bacteria. GT measured with M2 methods were systematically higher than those measured by M1. For studies with M1 methods, both GRF and GT were positively correlated to temperature, bacterial abundance and production. GT were also correlated to heterotrophic nanoflagellate abundance. GT and GRF showed a different pattern of change with temperature, GRF increased with temperature within the range 0 to $30^{\circ} \mathrm{C}$, while $G T$ increased only up to $18^{\circ} \mathrm{C}$. We did not find any satisfactory multiple regression model that explained the variation in the GT measurements with M2 methods. For M1 methods, flagellate abundance and temperatures below $18{ }^{\circ} \mathrm{C}$ were the main factors affecting $G T$ (the model explained $78 \%$ of the variance). While bacterial and flagellate abundances were the main factors at higher temperatures, the model in this case explained only $19 \%$ of the variance. Grazing rates could be affected by other sources of variability not considered here (e.g. prey and predator size, chlorophyll). These effects could become much more conspicuous above certain temperatures $\left(18^{\circ} \mathrm{C}\right.$ in our study).
\end{abstract}

KEY WORDS: Grazing rates - Temperature - Bacteria $\cdot$ Heterotrophic flagellates $\cdot$ Ciliates $\cdot$ Methodology

\section{INTRODUCTION}

Loss rates of bacteria are attributed to predation by a variety of planktonic organisms including heterotrophic flagellates (Fenchel 1982a, Sherr et al. 1984, Bloem et al. 1989), ciliates (Sherr et al. 1987, 1989), rotifers (Sanders et al. 1989), cladocerans (Turner et al. 1988, Pace et al. 1990, Vaqué \& Pace 1992), appendicularians (King et al. 1980) and copepods (Pedrós-Alió \& Brock 1983). Alternative loss processes have not been clearly defined for bacteria (Pace 1988) with the exception of the potentially significant viral mortality recorded in coastal oceans (Bratbak et al. 1990, 1992).

\footnotetext{
- This paper is dedicated to the memory of Russell T. Bell
}

The main loss factor for bacteria, however, is generally assumed to be the grazing by protists, mainly heterotrophic nanoflagellates (Sanders et al. 1989, 1992). These organisms have the potential for removing entire bacterial populations at in situ concentrations (Fenchel 1982a, b), and they clearly demonstrate this potential when water samples free of protist predators are enclosed and allowed to evolve (Andersen \& Fenchel 1985, Bloem \& Bär-Gilissen 1989).

Ingestion rates of bacteria by protists probably respond to different environmental and biological variables (e.g. temperature, food concentration, bacterial production and even competition among predators). Changes in bacterial abundance modify protist activity (e.g. the functional response; Fenchel 1980, 1982a, b). 
Bacterial production, and probably abundance, increase with temperature (White et al. 1991) and these increases could favor a higher bacterial ingestion rate by the protists (Choi \& Peters 1992), an increase in the overall community rates (Marrasé et al. 1992), and perhaps an increase in the abundance of bacterial consumers. However a greater abundance of consumers may be reflected in lower specific grazing rates due to competitive interference (Curds \& Cockburn 1968).

In addition, the measured grazing rates on bacteria could also depend on the method used to measure the process. The most frequently used methods are those that measure grazing rates by microscopic observation of ingested tracer particles per individual protist (fluorescent microspheres, Sanders et al. 1989; fluorescently labelled bacteria, Sherr et al. 1987; minicells, Pace et al. 1990) or determining the disappearance of fluorescent or radioactive particles with time (Wikner et al. 1986, Pace et al. 1990, Marrasé et al. 1992, Vaqué et al. 1992). Other methods measure grazing by comparing the bacterial abundances in manipulated and unmanipulated samples. These methods include differential filtration (Kuuppo-Leinikki \& Kuosa 1990), dilution (Landry et al. 1984, Weisse 1990), selective protist inhibition (Coffin \& Sharp 1987, Scavia \& Laird 1987, Caron et al. 1991), and radioisotope labelling with ${ }^{14} \mathrm{C}$ or ${ }^{3} \mathrm{H}$ (Nygaard \& Hessen 1990).

We collected a data set from published field studies in order to examine the relative importance of biological, environmental and methodological variables in the measurements of specific and community grazing rates of protists at in situ concentrations. Variables like protist predator and bacterial size were not analyzed, despite having the potential of being extremely useful (Moloney \& Field 1989, Peters 1994) as they are rarely reported in field studies. Furthermore, there is considerable variation in bacterial size measurements among researchers (Cole et al. 1993).

Table 1. Data sources used in the analysis. System, variables obtained, number of individual points obtained ( $\mathrm{n}$ ), and method used to measure grazing rates. Variables: $T$, temperature; $B N$, bacterial abundance; $G T$, community grazing rates; $G R F$, flagellatespecific grazing rates $H N F$, heterotrophic nanoflagellate abundance; $B P$, bacterial production. Methods: 1 , uptake of inert particles; 2, uptake of fluorescently labelled bacteria (FLB); 3, uptake of fluorescently labelled minicells; 4, dilution; 5, selective inhibition; 6 , radioactively labelled bacteria; 7 , selective filtration; 8 , long-term disappearance of minicells or FLB

\begin{tabular}{|c|c|c|c|c|}
\hline System & $\mathrm{n}$ & Variables & Source & Method \\
\hline \multicolumn{5}{|l|}{ Lakes } \\
\hline Lake Oglethorpe, GA, USA & 31 & $T, B N, G T, G R F, H N F, B P$ & $\begin{array}{l}\text { Sanders et al. (1989) } \\
\text { Bennet et al. (1990) }\end{array}$ & 1 \\
\hline Rimov Reservoir, Czech Republic & 4 & $T, B N, G T, G R F, H N F$ & Šimek et al. (1990a) & 1 \\
\hline Rimov Reservoir, Czech Republic & 17 & $T, B N, G R F, H N F$ & Simek \& Straskrabová (1992) & 2 \\
\hline Rimov Reservoir, Czech Republic & 12 & $T, B N, G T, G R F, H N F$ & Simek et al. (1990b) & 1 \\
\hline Paul \& Tuesday Lakes, MI, USA & 15 & $T, B N, G R F, H N F$ & Vaqué \& Pace (1992) & 3 \\
\hline Upton Lake, NY, USA & 9 & $T, B N, G R F, H N F, B P$ & Pace et al. (1990) & 3,8 \\
\hline Lake Vechten, The Netherlands & 10 & $T, B N, G R F, H N F$ & Bloem et al. (1989) & 2 \\
\hline Lake Plußsee, Germany & 23 & $T, B N, G R F, G T, H N F, B P$ & Fukami et al. (1991) & 2 \\
\hline Great Lakes, N America & 5 & $B N, G T, H N F, B P$ & Weisse (1991) & 4 \\
\hline Lake Constance, W Europe & 24 & $T, B N, G T, H N F$ & Weisse (1990) & 4 \\
\hline Lake Michigan, USA & 10 & $T, B N, G T$ & Scavia \& Laird (1987) & 5 \\
\hline \multicolumn{5}{|l|}{ Rivers } \\
\hline Hudson River, USA & 6 & $T, B N, G R F, G T, H N F, B P$ & Vaqué et al. (1992) & 3,8 \\
\hline Ogeechee River, GA, USA & 6 & $T, B N, G R F, G T, H N F$ & Carlough \& Meyer (1990) & 2 \\
\hline Ogeechee River, GA, USA & 7 & $T, B N, G R F, G T, H N F$ & Carlough \& Meyer (1991) & 2 \\
\hline Butrón River, Spain & 9 & $T, B N, G R F, G T, H N F$ & Barcina et al. (1991) & 2 \\
\hline \multicolumn{5}{|l|}{ Marine } \\
\hline Kaneohe Bay, HI, USA & 2 & $B N, H N F, G T$ & Landry et al. (1984) & 4 \\
\hline Skagerrak & 5 & $T, B N, G T, H N F, B P$ & Rosenberg et al. (1990) & 6 \\
\hline Finland Gulf & 4 & $T, B N, G R F, H N F, B P$ & Kuuppo-Leinikki \& Kuosa (1990) & 7 \\
\hline Delaware Estuary, USA & 34 & $B N, H N F, G T$ & Coffin \& Sharp (1987) & 5 \\
\hline Vineyard Sound, MA, USA & 3 & $T, B N, G R F, H N F$ & Caron et al. (1991) & 5 \\
\hline Vineyard Sound, MA, USA & 19 & $T, B T, G T, H N F$ & Marrasé et al. (1992) & 8 \\
\hline Chesapeake Bay, USA & 17 & $T, B N, G R F, H N F, B P$ & McManus \& Fuhrman (1988) & 1 \\
\hline Red Sea & 17 & $T, B N, G T, H N F, B P$ & Weisse (1989) & 5 \\
\hline Bothnian Sea & 10 & $T, B N, G T, H N F, B P$ & Wikner et al. (1990) & 6 \\
\hline Bothnian \& Mediterranean Sea & 6 & $T, B N, G T, H N F, B P$ & Wikner et al. (1986) & 6 \\
\hline Mediterranean Sea & 2 & $B N, G T, H N F, B P$ & Hagstrom et al. (1988) & 6 \\
\hline Sargasso Sea & 3 & $B N, G R F, H N F$ & Pace \& Bailiff (1987) & 1 \\
\hline
\end{tabular}


In this study we seek to (1) identify the factors that are relevant in controlling bacterial carbon flux through protists, (2) identify differences among methods, and (3) provide empirical tools to predict grazing rates on bacteria which could be useful in cases where rates need to be estimated for budgeting and theoretical studies.

\section{METHODS}

We collected all simultaneous observations of grazing rates, temperature, and additional biological variables that we could find in the literature from the last decade (Table 1). We examined a total of 28 independent studies, involving 10 lakes, 3 rivers, and 10 marine environments. A total of 310 observations formed the core of the data set. Some reports had to be complemented with others that included variables of interest not available in the main report. We gathered 202 observations for total community grazing rates $(G T)$, and 186 observations for specific grazing rates of heterotrophic nanoflagellates (GRF). We considered studies of both freshwater and marine systems ranging from oligotrophy (e.g. Lake Michigan, Sargasso Sea) to eutrophy (e.g. Lake Vechten, The Netherlands; Delaware Estuary, USA) with the only restriction being the availability of simultaneous measurements of at least 3 of the variables of interest. The bacterial and heterotrophic nanoflagellate abundance measurements were based on epifluorescence counts using standard methods (AODC or DAPI staining). Bacterial production was measured by thymidine incorporation or with the dilution method (in those reports that analyzed grazing on bacteria with this method). Six reports measured grazing via uptake of fluorescently labelled latex particles, 6 reports with fluorescently labelled bacteria (FLB), 3 with fluorescently labelled minicells, 3 used the disappearance of FLB or minicells, 4 with the dilution and filtration methods, 4 with inhibitors, and 4 with the genetically labelled minicells (Table 1).

We focused our analysis on the following dependent variables: GRF [bacteria (per heterotrophic nanoflagellate, $\mathrm{HNF}^{-1}$ ) $\mathrm{h}^{-1}$ ] and $G T$ (bacteria $\mathrm{ml}^{-1} \mathrm{~h}^{-1}$ ) and used the following independent variables when available: $B N$ (bacterial abundance, cells $\mathrm{ml}^{-1}$ ), HNF (heterotrophic nanoflagellate abundance, cells $\mathrm{ml}^{-1}$ ), $T$ (temperature, ${ }^{\circ} \mathrm{C}$ ), and $B P$ (bacterial production, bacteria produced $\mathrm{ml}^{-1} \mathrm{~h}^{-1}$ ).

First, methodological differences were evaluated. Following the analysis reported in Fig. 1 (see 'Results') we divided the methods into 2 groups, M1 and M2. M1 methods were those that measured overall grazing rates per individual protist by microscopic observation of ingested marked particles (e.g. Pace \& Bailiff 1987 , Sherr et al. 1987, Pace et al. 1990), using short-term incubations. We also included in the M1 group the disappearance of fluorescently labelled particles with time (e.g. Pace et al. 1990), which measures total grazing rates on bacteria (GT, see 'Results' and 'Discussion'). M2 methods were those which measure total community rates (GT) using either dilution, inhibition, filtration, or uptake of radiolabelled particles (e.g. Wikner et al. 1986, Coffin \& Sharp 1987, KuuppoLeinikki \& Kuosa 1990, Weisse 1990). Authors using M2 methods frequently calculated flagellate-specific grazing rates by dividing the total grazing by flagellate abundance, and assuming that the major contribution to grazing was due to flagellate activity. Making the same assumption, several authors using $\mathrm{M} 1$ approaches calculated total grazing by multiplying specific grazing rate by flagellate abundance. We decided not to include the data which were calculated under this assumption in order to avoid the introduction of sources of variability or bias other than experimental errors in data collection. Instead, values of total community rates using $\mathrm{M} 1$ methods were calculated as the sum of grazing rates by flagellates and ciliates on bacteria:

$$
G T=G R F \times H N F+G R C \times C I L
$$

where $G T=$ total community grazing rate; $G R F=$ flagellate-specific grazing rate ${ }_{i} H N F=$ heterotrophic nanoflagellate abundance; $G R C=$ ciliate-specific graz-

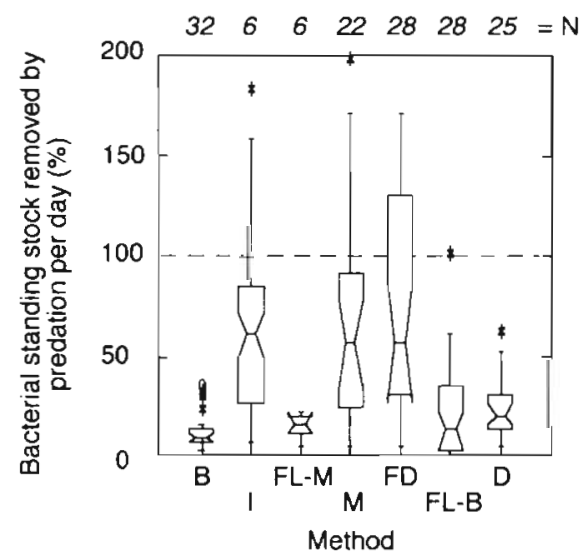

Fig. 1. Box-whisker plot of mean percentage of bacterial standing stock removed daily by predation according to the method used. B: fluorescent beads; I: protists inhibitors; FL-M: minicells; M: radiolabelled minicells; FD: filtration and dilution; FL-B: fluorescently labelled bacteria; $D$ : fluorescent particle disappearance. Also shown, the number of individual observations $(\mathrm{N})$. The central line of the box is the median of the distribution, and the box limits are the $25 \%$ quartiles of the data. The whiskers cover the entire data range, except very extreme observations (*), some of which in groups I, M and FD are off-scale 
ing rate and $C I L=$ ciliate abundance. In these studies performed using short-term experiments ( 1 to $2 \mathrm{~h}$ ), it is assumed that the 2 most important predators are ciliates and flagellates. Although grazing by ciliates is frequently reported, only a few studies reported ciliate abundances. For this reason we could not consider this variable in our statistical analysis (see 'Results').

Except for temperature, all other variables were $\log _{10}$-transformed before the analysis to equalize variance and meet the assumptions of least square regression analysis. The data were analyzed with the general linear model hypothesis module of Systat (Wilkinson 1989). We used multiple regression, controlling for the addition or removal of predictor variables. Best models were considered to be those that maximized the $r^{2}$ and minimized the standard error of the estimate, with the minimum number of predictive variables possible. $\beta$-coefficients (standardized partial regression coefficients) were used to compare the relative impact of each predictor variable in the independent variable.

\section{RESULTS}

\section{Methodological considerations}

A variety of methods have been used to measure protist grazing rates on bacteria. Significant differences exist among the percentages of the bacterial standing stock grazed per day depending on the different methodologies used by different authors (Fig. 1). This percentage was always lower when fluorescent particles (latex, minicells or FLB) were used than when grazing measurements were conducted using inhibition, radiolabelled particles, or filtration-dilution methods (1-way ANOVA, $F=42.1, p<0.0001$ ). Measured rates by fluorescent particle methods were not significantly different among themselves $(F=0.03, \mathrm{p}=0.86)$. Therefore, we decided to include all these methods in 1 group (M1 methods). This group included grazing rates on bacteria estimated through the microscopic observation of the ingestion of labelled particles plus the estimates based on the long-term disappearance of labelled particles. Although this last technique includes the grazing by predators other than protists, total rates of grazing were not significantly different from those estimated by the uptake of particles ( $F=$ $0.35, p=0.56)$. Grazing rates estimated with the dilution, inhibition or genetically labelled minicells methods were not significantly different among
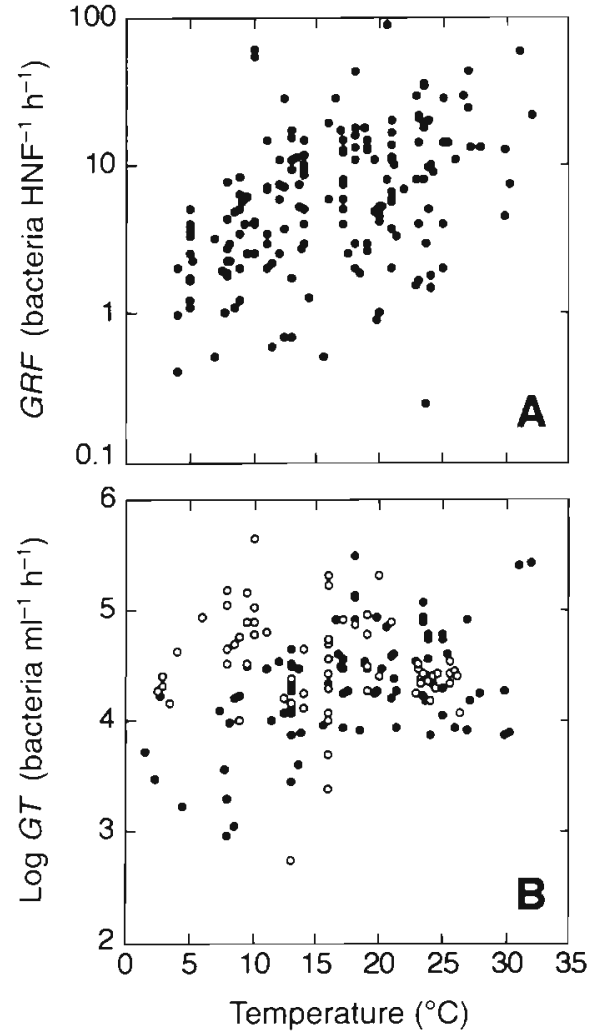

Fig. 2. Relationship between temperature and (A) specific grazing rates of flagellates, $G R F$, and (B) total community grazing rates, GT, with M1 methods $(\bullet)$ and M2 methods $(0)$. See text for details

themselves $(F=0.09, \mathrm{p}=0.78)$ and, thus, we pooled all these values in the M2 group. Some of the percentages of bacterial standing stock removed per day for M2 methods are extremely high (Fig. 1) and appear to be unreliable (e.g. $400 \%$ of bacterial standing stock removed per day; in this case the bacterial population would collapse in a short time). The statistical analyses

Table 2. Number of cases ( $n$ ), mean values, and coefficient of variation (CV) for the dependent variables studied (total grazing, bacteria $\mathrm{ml}^{-1} \mathrm{~h}^{-1}$; and HNF grazing, bacteria $H N F^{-1} h^{-1}$ ) and for each group of methods. $R, L$ and $S$ indicate rivers, lakes and seawater respectively

\begin{tabular}{|ccrcrrrr|}
\hline Methods & System & \multicolumn{3}{c}{ Total grazing } & \multicolumn{3}{c|}{ HNF grazing } \\
& & $\mathrm{n}$ & Mean & $\mathrm{CV}$ & $\mathrm{n}$ & Mean & $\mathrm{CV}$ \\
\hline M1 & $\mathrm{R}$ & 40 & $5.8 \times 10^{4}$ & $125 \%$ & 43 & 17.3 & $97 \%$ \\
M1 & $\mathrm{L}$ & 32 & $1.8 \times 10^{4}$ & $58 \%$ & 122 & 7.6 & $116 \%$ \\
M1 & $\mathrm{S}$ & 19 & $2.9 \times 10^{4}$ & $105 \%$ & 21 & 6.0 & $97 \%$ \\
M2 & $\mathrm{R}$ & 0 & & & & & \\
M2 & $\mathrm{L}$ & 36 & $6.5 \times 10^{4}$ & $117 \%$ & & & \\
M2 & $\mathrm{S}$ & 75 & $4.7 \times 10^{4}$ & $113 \%$ & & & \\
M1 & All & 91 & $3.8 \times 10^{4}$ & $139 \%$ & 186 & 9.7 & $121 \%$ \\
M2 & All & 111 & $5.0 \times 10^{4}$ & $117 \%$ & & & \\
\hline
\end{tabular}



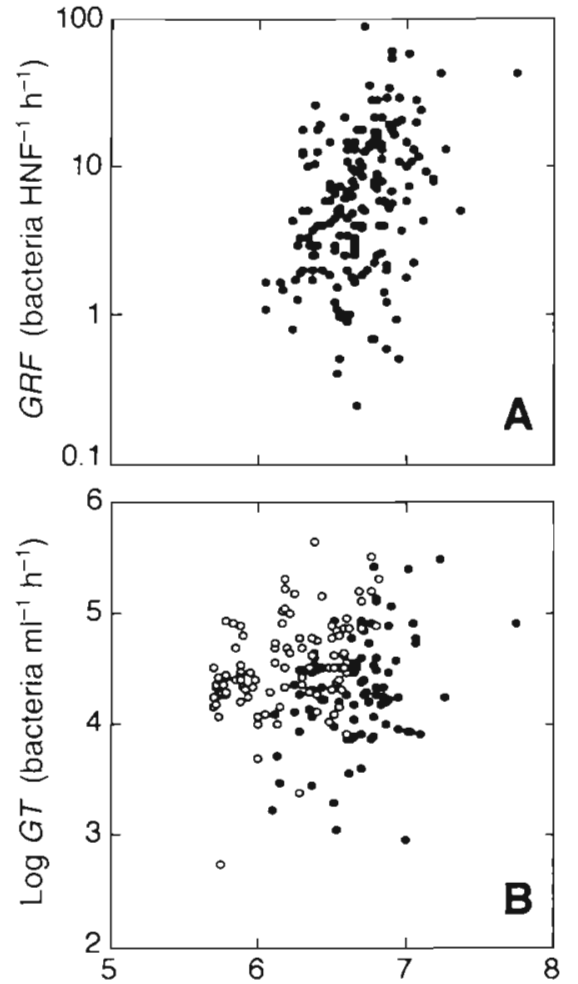

Log bacterial abundance (bacteria $\mathrm{ml}^{-1}$ )

Fig. 3. Relationship between bacterial abundance and (A) specific grazing rates of flagellates, GRF, and (B) total community grazing rates, $G T$, with $M 1$ methods $(\bullet)$ and $M 2$ methods (0)

that follow were made independently for these 2 groups (M1 and M2).

Average total community ingestion rates $(G T)$ in the studies where M2 methods had been used were slightly higher than those where M1 methods were used, comparing similar systems (Table 2). Average GT were higher in rivers, followed by marine systems and lakes. Average specific flagellate grazing rates (GRF) were also higher in rivers (17.3 bacteria HNF $^{-1}$ $\mathrm{h}^{-1}$ ) than in lakes ( 7.6 bacteria $\mathrm{HNF}^{-1} \mathrm{~h}^{-1}$ ) or seawater $\left(6.0\right.$ bacteria $\left.\mathrm{HNF}^{-1} \mathrm{~h}^{-1}\right)$. Although these averages exhibited high variance, we systematically observed greater values of GT when M2 methods were used (Table 2).

\section{Effects of temperature and biological factors on grazing rates}

Both GRF and GT on bacteria were significantly and positively correlated to temperature for $\mathrm{M} 1$ methods ( $\mathrm{n}=182, \mathrm{r}=0.45, \mathrm{p}<0.0001 ; \mathrm{n}=91, \mathrm{r}=0.46, \mathrm{p}<0.0001$ respectively; Fig. $2 \mathrm{~A}, \mathrm{~B})$. While $G R F$ increased with temperature, GT seemed to reach a plateau at ca $18^{\circ} \mathrm{C}$
(Fig. 2A, B). GT were not related to temperature for M2 methods (Fig. 2B).

Bacterial abundance was positively correlated with GRF ( $\mathrm{n}=181, \mathrm{r}=0.40, \mathrm{p}<0.0001$; Fig. $3 \mathrm{~A}$ ) for $\mathrm{M} 1$ methods and with $G T$ for both $\mathrm{M} 1$ and $\mathrm{M} 2$ methods $(\mathrm{n}=111, \mathrm{r}=0.38, \mathrm{p}<0.0001 ; \mathrm{n}=91, \mathrm{r}=0.32, \mathrm{p}=0.002$ respectively; Fig. $3 \mathrm{~B}$ )

Bacterial production (BP) showed a significant positive relationship with $G R F$ and $G T(\mathrm{n}=77, \mathrm{r}=0.46$, $\mathrm{p}<0.0001 ; \mathrm{n}=49, \mathrm{r}=0.57, \mathrm{p}<0.0001$ respectively; Fig. 4A, B) but only for the M1 methods. No significant relationship was found between $B P$ and $G T$ when the M2 methods were considered (Fig. 4B).

No significant relationship was detected between $G R F$ and HNF (Fig. 5A). Conversely, a positive relationship was found between GT and HNF for both M1 and M2 methods $(n=66, r=0.54, p<0.0001$; and $n=100, r=$ $0.27, p=0.007$ respectively; Fig. 58). To further evaluate the effect of $H N F$ on grazing rates, we excluded those samples that used the disappearance of labelled particles, because studies using these methods occasionally found significant bacteria grazing due to organisms other than protists (Sanders et al. 1989, Pace et al. 1990.
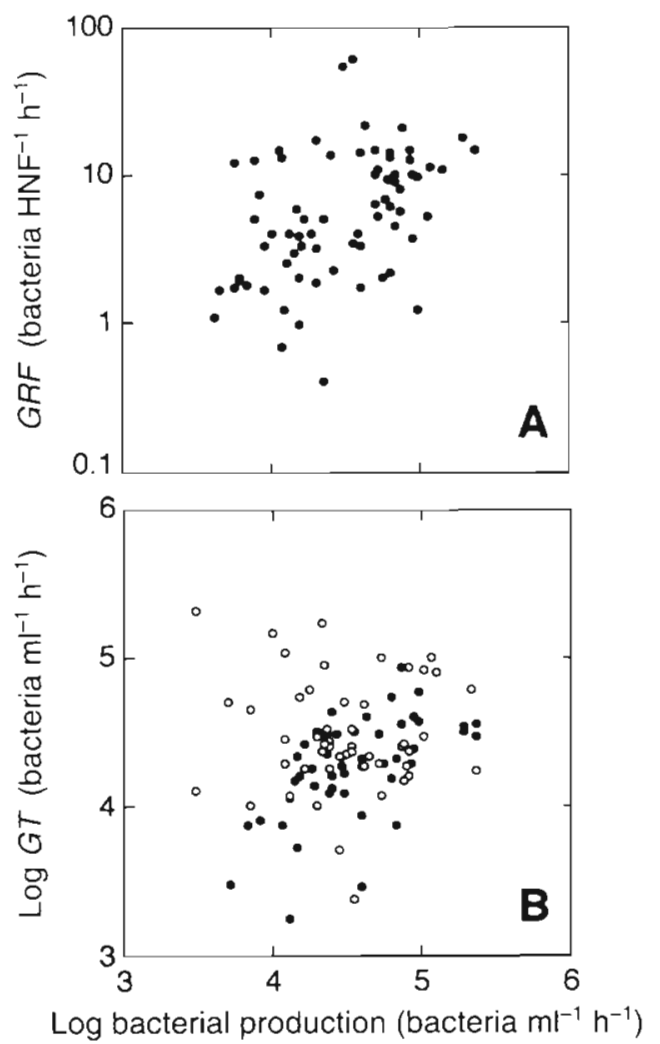

Fig. 4. Relationship between bacterial production and (A) specific grazing rates of flagellates, GRF, and (B) total community grazing rates, GT, with M1 methods $(\bullet)$ and $M 2$ methods $(0)$ 

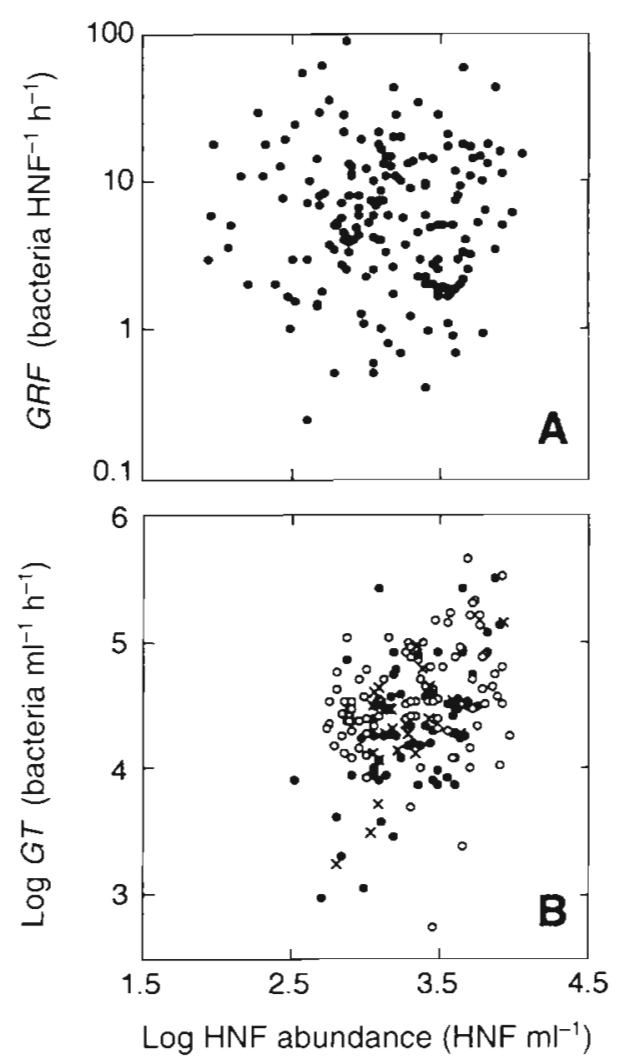

Fig. 5. Relationship between flagellate abundance and (A) specific grazing rates of flagellates, $G R F$, and (B) total community grazing rates, $G T$, with M1 methods $(\bullet)$ and M2 methods $(0)$ and those estimates obtained through the long-term disappearance of labelled bacteria $(x)$

Vaqué et al. 1992). However, GT obtained with this method (Fig. 5B) were also positively correlated to HNF abundance $(n=25, r=0.58, p=0.002)$.

\section{Best models to estimate community grazing rates}

The best linear model to predict GT was found when only M1 methods were considered (excluding the disappearance method, for the reasons described above) and the following independent variables (all significant with $\mathrm{p}<0.01$ ): heterotrophic nanoflagellate abundance ( $H N F$ ), temperature $(T)$ and bacterial abundance $(B N)$. The plot of observed vs predicted values (Fig. 6A) showed no obvious outliers. The equation was:

$\log G T=-3.21+0.99 \log H N F+0.028 T+0.55 \log B N(1)$

$\left(\mathrm{n}=66\right.$, adjusted $\left.\mathrm{r}^{2}=0.53, \mathrm{p}<0.0001\right)$ with $\beta$-coefficients $=0.59,0.35$ and 0.25 respectively.

GT increased with temperature (Fig. 2B) up to ca $18^{\circ} \mathrm{C}$. We used a LOWESS (Cleveland 1979) fit to the data to detect the inflection point. When rerunning the
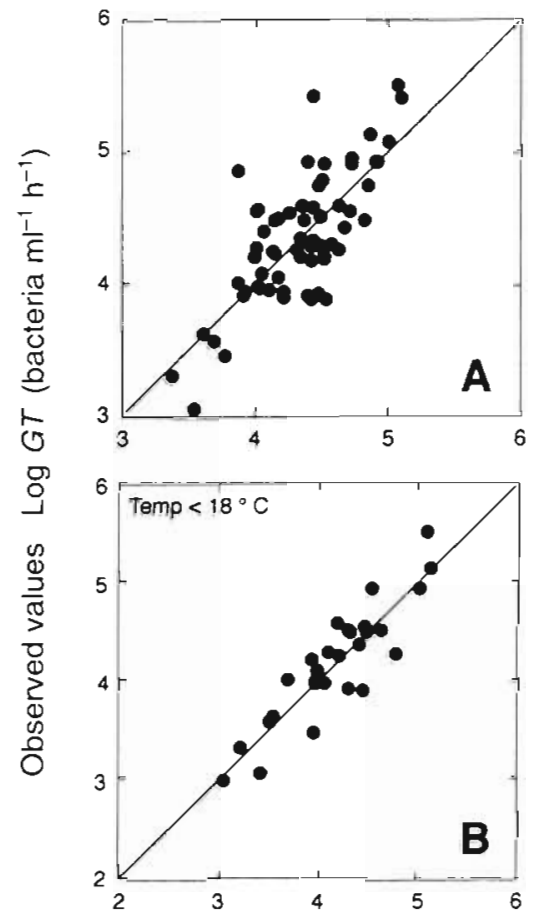

Predicted values $\log G T$ (bacteria $\mathrm{ml}^{-1} \mathrm{~h}^{-1}$ )

Fig. 6. Relationship between observed total community grazing rates, GT, and predicted GT, with Model 1 (in text) for (A) all temperatures and $(B)$ temperatures $<18^{\circ} \mathrm{C}$. Equation for predicting $G T$ in $(\mathrm{A}): \log G T=-3.21+0.99 \log H N F+0.028 T$ $+0.55 \log B N_{i}(\mathrm{~B}) \log G T=-0.64+1.16 \log H N F+0.071 T$

analysis with temperatures $<18^{\circ} \mathrm{C}$, bacterial abundance was no longer a significant variable and the model explained much more variance (78\%). The equation was:

$$
\log G T=-0.64+1.16 \log H N F+0.07 T
$$

( $\mathrm{n}=28$, adjusted $\mathrm{r}^{2}=0.78, \mathrm{p}<0.0001$ ) with $\beta$-coefficients $=0.66$ and 0.42 respectively. Inspection of the observed vs predicted plot did not reveal any outliers (Fig. 6B).

For temperatures $>18^{\circ} \mathrm{C}$, a very small percentage of the variability was explained by the best model. The model, obviously, did not include temperature but included bacterial and flagellate abundances ( $B N$ and HNF), which were only slightly significant:

$$
\log G T=-1.99+0.59 \log H N F+0.66 \log B N
$$

( $\mathrm{n}=38$, adjusted $\left.\mathrm{r}^{2}=0.19, \mathrm{p}=0.01\right)$ with $\beta$-coefficients $=0.40$ and 0.37 respectively.

The only variable correlated to $G T$ for the $\mathrm{M} 2$ methods was $B N$ and explained only $14 \%$ of the variance $\left(\mathrm{n}=93, \mathrm{r}^{2}=0.14, \mathrm{p}<0.0001\right)$. 


\section{Best models to estimate specific grazing rates by flagellates}

No models explained a high percentage of the variability in GRF. The only statistically significant model was for M1 methods where $T$ and $B N$ were significantly related to $G R F$ :

$$
\log G R F=-3.27+0.024 T+0.55 \log B N
$$

( $\mathrm{n}=177$, adjusted $\mathrm{r}^{2}=0.27, \mathrm{p}<0.0001$ ) with $\beta$-coefficients $=0.35$ and 0.29 respectively.

Because only 6 points had estimated GRF with $\mathrm{M} 2$ methods, we did not try any further analysis with this group of data.

\section{Performance of the models}

We used recently published particle uptake data (from Barcina et al. 1992 and Epstein \& Shiaris 1992) and unpublished data of our own to test Models (1) and (2) with data different from those used to build the models (Fig. 7A). The data from Barcina et al. (1992) consisted of flagellate grazing rates obtained with FLBs, while Epstein \& Shiaris (1992) reported grazing by both flagellates and ciliates. The other data set was composed of unpublished minicell disappearance rates from the Catalonian coastal area, and the open Catalan Sea (both from NW Mediterranean), and long-term minicell or FLB disappearance rates corresponding to the measurements done in the Hudson River (Vaqué et al. 1992) and in Woods Hole (Marrasé et al. 1992), USA. Total grazing rates obtained with Models (1) and (2) should be higher than flagellate-only grazing rates, and lower than total disappearance rates (if metazoans

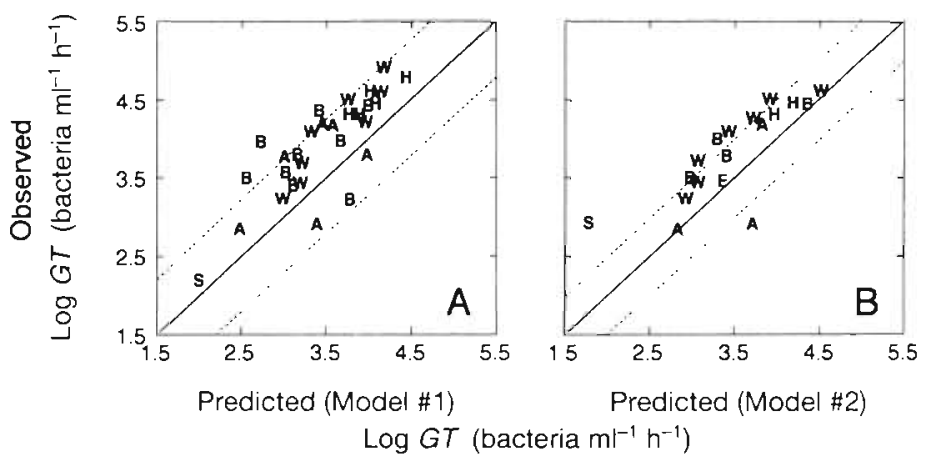

Fig. 7 Relationship between observed total community grazing rates, $G T$, and predicted $G T$, with (A) Model 1 and (B) Model 2 for observations not used to build the models: B: Blanes coastal area (Catalonia); S: open Catalan Sea; W: Woods Hole, MA, USA; H: Hudson River, USA; A: La Salvaje Beach, Spain (Barcina et al. 1992); E: Boston Harbor, MA, USA (Epstein \& Shiaris 1992). The 95\% confidence interval for the prediction and the 1:1 line are also shown eating bacteria have some impact ). As expected, predicted rates are lower (less than half an order of magnitude) than observed disappearance rates (points labelled W, B and $\mathrm{H}$ in Fig. 7), and some of the values of flagellate grazing obtained by Barcina et al. (1992) are lower than those expected (points labelled $A$ in Fig. 7), or on the 1:1 line (points labelled E from Epstein \& Shiaris 1992; Fig. 7). Only 2 out of the 6 samples obtained from the Barcina et al. (1992) study are below the line, a result which agrees with the authors' observation that flagellates should be the dominant grazers in their system. Only 2 observations are greatly underestimated by our models (point labelled $S$, from the open Catalan Sea and another point off-scale). The abundances of bacteria and heterotrophic flagellates in the oligotrophic Catalan Sea were extremely low at the time of these experiments (unpubl. results) and thus, outside the range of values used to build the models. Extrapolation beyond the range of the variables used to build regression models is unreliable (Wilkinson 1989). The observed values for the disappearance rate measurements were highly correlated to the predicted values $\left(n=13, r^{2}=0.88, p<0.0001\right.$; Fig. $7 \mathrm{~B}$ ) but the slope was significantly lower than 1 ( $b=0.764 \pm 0.084)$, suggesting that loss factors for bacteria other than protists should be important mainly in the most oligotrophic systems.

\section{DISCUSSION}

Differences in specific grazing rates on bacteria are notable when comparing experimental data to field data. In experiments performed with cultured marine and limnetic flagellate species, specific grazing rates of flagellates are usually higher than in the field experiments reported in Table 2. Fenchel (1982a) found wide ranges (27 to 254 bacteria $\mathrm{HNF}^{-1}$ $\mathrm{h}^{-1}$ for marine species and 54 to 194 bacteria $\mathrm{HNF}^{-1} \mathrm{~h}^{-1}$ for limnetic species) in experiments carried out at $20^{\circ} \mathrm{C}$; Davis \& Sieburth (1984) determined 50 to 121 bacteria $\mathrm{HNF}^{-1} \mathrm{~h}^{-1}$ for marine species incubated at $21^{\circ} \mathrm{C}$, and Choi \& Peters (1992) found values ranging from 14 bacteria $\mathrm{HNF}^{-1} \mathrm{~h}^{-1}$ at $-1.5^{\circ} \mathrm{C}$ to 99 bacteria $\mathrm{HNF}^{-1}$ $\mathrm{h}^{-1}$ at $15^{\circ} \mathrm{C}$ for marine species. The average value for M1 methods in Table 2 was 9.7 bacteria $\mathrm{HNF}^{-1} \mathrm{~h}^{-1}$ (range: 0.25 to 90 bacteria $\mathrm{HNF}^{-1}$ $\mathrm{h}^{-1}$ ). The higher values from culture experiments could be due to: (1) optimum growth conditions for bacteria and flagellates; (2) the fact that both bacteria and flagellates are usually present in high concentrations (higher than in situ concentrations); or (3) that bacterial cells are usually larger in culture than in situ. As these 
conditions are unlikely to occur in the field and we wished to predict protist grazing in natural systems, we specifically avoided the use of data from laboratory cultures in our models.

\section{Assessment of methods}

We found a significant difference in grazing rates between $\mathrm{M} 1$ and M2 methods. A great number of GT values estimated with $M 2$ methods accounted for a dramatically high percentage of bacterial standing stock (mean $76 \%$, range 2 to $436 \%$ daily). The average for M1 methods was more moderate: $17 \%$ daily (range 0.2 to $104 \%$ ). Differences between M1 and M2 methods do not appear to be related to differences among environments (marine vs freshwater; Table 2). Thus, our results suggest that there are systematic differences between these methods which are associated with their intrinsic characteristics. Possible reasons for the extremely high values of GT could simply be that they include sources of mortality for bacteria other than protistan predation (e.g. metazoans, viruses). Also, the manipulation of samples associated with M2 methods (filtration, dilution, inhibitors, and sometimes long-term incubations) can facilitate changes in the abundance and activity of the original heterotrophic communities. There may be shifts in the bacterial populations during manipulation, increasing the amount of nutrients available to bacteria. Temperature is an important factor, especially when the experiments are not performed at in situ temperature. Marrasé et al. (1992) compared bacterial loss rates at in situ and at laboratory temperatures $\left(20^{\circ} \mathrm{C}\right)$ and found a constant discrepancy between rates associated with the temperature shift. As we have shown above (Fig. 2), temperature does significantly affect the grazing rate estimates.

Filtration implies the removal of predators of protistans, thus allowing a fast growth of flagellates which significantly reduce bacterial populations in a short period (see examples in Andersen \& Fenchel 1985, and Bloem \& Bär-Gilissen 1989). Furthermore, filtration can induce an enrichment in organic and inorganic nutrients, thus increasing bacterial growth. Grazing rates on bacteria under these circumstances are not necessarily equivalent to those occurring before the manipulation.

In studies where filtration through $1 \mu \mathrm{m}$ filters is used, all organisms are removed including the direct or indirect producers of growth substances for bacteria. Reduction of the substrate pool could cause bacteria to stop growth (Güde 1986). Dilution of a sample could potentially prevent substrate exhaustion, but then an overestimate of the bacterial growth rates could be obtained if bacterial growth in situ were substratelimited (which is likely always to be the case; Kirchman 1990, Toolan et al. 1991, Coveney \& Wetzel 1992, Morris \& Lewis 1992). As the dilution procedure reduces bacterial density, the same amount of substrate would be available to fewer bacteria. Comparing bacterial growth rates by the dilution method to other estimates of bacterial activity in freshwater sediments, Gasol et al. (1993) found no correlation between both measurements of activity, and very high estimates from the dilution experiment. As a consequence, in these same experiments, bacterial loss rates by the dilution method were several orders of magnitude higher than estimates based on other methods (J. M. Gasol, B. Sander \& J. Kalff unpubl.). Bacterial loss rates in the dilution procedure are obtained from the slope of the regression between the undiluted fraction and the change in bacterial numbers. The growth rate is obtained from the intercept of such a regression. Thus, whatever the factor that alters growth rates will also alter the estimates of the loss rates.

The use of eukaryotic inhibitors may also cause artifacts. Some authors who use cycloheximide have indicated that ciliate grazing on bacteria is not entirely inhibited by this antibiotic (Sanders \& Porter 1986, Taylor \& Pace 1987). Another artifact associated with the use of antibiotics to inhibit bacteriovores may be an uncoupling of bacteria from the sources of regenerated nutrients (Sherr et al. 1986) crucial for bacterial growth. These artifacts imply high variability in the bacterial production measurements and associated high variability in the grazing measurements (see Fig. 1).

The method used by Wikner et al. (1986), the radiolabelled minicell uptake rate, gave significantly higher values of grazing than the uptake of fluorescent particles or disappearance of minicells and FLB. We expected to find similar results in comparison with those from studies using fluorescently labelled particles, because the only difference is in the manner of minicell labelling. More comparisons between these 2 methods need to be made to clarify the differences we detected.

The problems with some of the M2 methods could explain the weak relationships we found between grazing rates and the set of independent variables studied (see 'Results'). Although most of the M1 methods involve short-term incubations, they are, however, not free of problems. Protists may select against inert particles or dead bacteria (Landry et al. 1991), and they may eject some of the ingested particles (Pace \& Bailiff 1987, Sieracki et al. 1987. McManus \& Okubo 1991). However, these methods gave consistent results that varied as expected with the environmental variables. It is possible that part of the unexplained variance in the 
models reported above are related to some of these problems, as well as to differences among researchers, and probably to the size-selective feeding behavior of flagellates and ciliates (Fenchel 1980, González et al. 1990, Simek \& Chrzanowski 1992). If the particle (minicells, latex beads, even FLB if they were not made from the same sample) size does not overlap with the natural bacteria size distribution, the estimates of grazing could be over- or underestimates.

The disappearance of marked cells is the only method included in $\mathrm{M} 1$ which requires long-term incubations ( 24 to $48 \mathrm{~h}$ ). However, no statistical differences in the grazing rates were found between this method and those measuring community rates $(G T)$ in shorttime incubations. The samples were neither filtered nor diluted and, in all the studies available, the incubations were made at in situ temperature (Pace et al. 1990, Marrasé et al. 1992, Vaqué et al. 1992). In addition, the same substrate (fluorescent particles) for bacterial consumers was used and, in these experiments, flagellates and ciliates were the main predators on bacteria. These experimental conditions could perhaps explain why the estimates using this method were similar to those of the M1 methods.

It is possible that some of the apparent differences between $\mathrm{M} 1$ and $\mathrm{M} 2$ methods were related to the particular ecological conditions of the sites where these techniques were applied, and not to the methodology. We can analyze the effects of temperature, bacteria, and heterotrophic flagellate abundance in the studies that used each method. There were no differences in the ranges of each of these 3 variables when analyzed by method (M1 vs M2; Table 3). Mean bacterial abundance was slightly higher for M1 methods, but this did not result in higher grazing rates for M1 methods as would have been expected. While we cannot com-

Table 3. Number of cases ( $\mathrm{n})$, averages, ranges and coefficients of variation (CV) of temperature $\left(T,{ }^{\circ} \mathrm{C}\right)$, bacterial abundance $\left(B N\right.$, bacteria $\left.\times 10^{6} \mathrm{ml}^{-1}\right)$, and heterotrophic nanoflagellate abundance ( $H N F$, flagellates $\times 10^{3} \mathrm{ml}^{-1}$ ) for each type of methods used (M1 and M2, see text)

\begin{tabular}{|lccc|}
\hline & $T$ & $B N$ & $H N F$ \\
\hline Methods M1 & & & \\
n & 204 & 201 & 206 \\
Average & 15.9 & 5.9 & 2.1 \\
Range & $1.5-32.0$ & $1.1-54.4$ & $0.09-11.0$ \\
CV & $44 \%$ & $89 \%$ & $93 \%$ \\
Methods M2 & & & \\
n & 90.0 & 131 & 120 \\
Average & 15.1 & 2.1 & 2.7 \\
Range & $0.7-26.4$ & $0.5-6.6$ & $0.4-9.0$ \\
CV & $45 \%$ & $71 \%$ & $78 \%$ \\
\hline
\end{tabular}

pletely exclude differences in ecological conditions as a determinant of the higher rates found with $\mathrm{M} 2$ techniques, we conclude that methodological differences are probably important

\section{Temperature and substrate regulation of feeding rates}

Temperature is an important variable determining protist feeding rates. Laboratory experiments found temperature to be positively correlated to the ingestion rate of Paraphysomonas imperforata feeding on diatoms (Caron et al. 1986) and on bacteria (Choi \& Peters 1992). These authors also found flagellate growth rate to be positively related to temperature for temperatures below $15^{\circ} \mathrm{C}$. Tobiesen (1990) studied several species of nano- and microflagellates and found temperature to be related to total and specific clearance rates. $\mathrm{He}$ also found temperature to be related to maximal flagellar speed, and flagellar speed to be related to clearance rate. Thus, he postulated that temperature affected feeding rates by changing water viscosity, which in turn affected flagellar speed. Further, bacterial growth rate was also found to be related to temperature in a literature survey that included many different habitats (White et al. 1991). When experiments of community grazing impact on bacteria were performed simultaneously at in situ temperatures and at $20^{\circ} \mathrm{C}$, rates in the laboratory were always significantly higher than those in the field for temperatures below ca $13^{\circ} \mathrm{C}$ (Marrasé et al. 1992). As the water temperature increased above 13 to $15^{\circ} \mathrm{C}$ the effect was no longer apparent. The data that we have analyzed, from very different systems, collected by different authors, and with different methods, confirm this pattern (Fig. 2). However, $G R F$ and $G T$ followed different patterns in their relation to temperature. GRF increased with temperature within the range 0 to $30^{\circ} \mathrm{C}$ (Fig. 2A), while $G T$ increased only up to $18^{\circ} \mathrm{C}$, and after this temperature there is no further increase (Fig. 2B). A possible explanation for this different behavior could be that while $G R F$ is a variable related to individual flagellate activity, GT refers to the total grazing of the community (including organisms other than flagellates) and is sensitive to other biological interactions (e.g. competition, top-down control).

Prey density is related to grazing rates when the density of the prey is below the half-saturation concentration (the functional response; e.g. Taylor 1984). Thus, we could expect bacterial abundance to be related to grazing losses. Half-saturation constants vary from 1.3 to $38 \times 10^{6}$ bacteria $\mathrm{ml}^{-1}$ (Fenchel 1982a, Jürgens 1992), well within the ranges of bacterial abundance in our data set. In fact, we found bacterial 
concentration to be consistently related to flagellate grazing rates (Model 4) and to total grazing rates (Model 1). However, the effect of 'food' concentration was only significant at temperatures above $18^{\circ} \mathrm{C}$ (Model 3).

Wiebe et al. (1992) found that the effect of substrate concentration (organic matter) on bacterial activity was related to temperature in a complex way. At temperatures above $15^{\circ} \mathrm{C}$ they did not detect any effect of substrate additions, while bacterial growth rate greatly increased at low temperatures when substrate was added. A similar scenario could be expected for the regulation of flagellate feeding rate and total impact on bacteria. However, we actually found the resource (bacterial abundance) to be important only for temperatures above $18^{\circ} \mathrm{C}$. This different behavior may be due to an interaction between bacterial abundances and temperature. Bacterial abundances are in general low at low temperatures (or at least they are lower than the half-saturation constants). When episodic algal blooms in low temperature water appear (e.g. during the winter of 1989-1990 in Vineyard Sound, MA, USA) and are followed by bacterial blooms, grazing rates on bacteria are usually higher than what we would expect from the low temperatures (see Fig. 3 in Marrase et al. 1992). Temperature seems to play a limiting role, as long as bacterial concentration does not exceed a certain level. When considering data from environments with temperatures lower than $18^{\circ} \mathrm{C}$ bacterial abundance was not significant, and temperature explained $42 \%$ of the total variance. Once the limiting effect of temperature is overcome, other factors seem to be more important. For temperatures $>18^{\circ} \mathrm{C}$, heterotrophic flagellate and bacterial abundances explained $15 \%$ and $4 \%$ of the variance respectively, and temperature was not significant. For the specific grazing rates of flagellate, bacterial abundance explained $7 \%$ of the total variance $(28 \%)$ described, while the variance explained by temperature itself was $21 \%$. Those were results obtained considering different systems. As we have discussed, when individual systems are studied, episodic events may allow grazing rates to be high even at low temperatures.

\section{Conclusion}

We conclude that the experimental protocol and the method chosen to determine grazing rates affect the actual values obtained. The choice of methods should depend on the kind of study to be conducted, and the limitations of each method should be acknowledged. Experimental studies comparing different methodologies are needed to corroborate and evaluate the systematic differences that we found among methodolo- gies. Our study also revealed that heterotrophic nanoflagellate abundance, temperature, and bacterial abundance were the main factors controlling bacterial grazing rates. However, factors such as protistan and bacterial mean sizes (Peters 1994), as well as abundances of predators other than protists (Sanders et al. 1989, Vaqué \& Pace 1992, Vaqué et al. 1992), could describe part of the unexplained variance in our models. Unfortunately those variables were not included in the models because they are usually not provided in the field reports.

Acknowledgements. We thank M. L. Pace, C. Pedrós-Alió and F. Peters for permission to use unpublished manuscripts, or for insightful comments on the manuscript, and M. H. MacLean for revising the text. We thank all authors who published data in a usable form and the editors who allowed them to do so. This work was supported by research projects of CICYT-MAR 91-0359 and -MAR 91-0503, DGICYT PB91-075 and MAS2CT93-0063.

\section{LITERATURE CITED}

Andersen, P., Fenchel, T. (1985). Bacterivory by microheterotrophic flagellates in seawater samples. Limnol. Oceanogr. 30: $198-202$

Barcina, I., Ayo, B., Muela, A., Egea, L., Iriberri, J. (1991). Predation rates of flagellate and ciliated protozoa on bacterioplankton in a river. FEMS Microbiol. Ecol. 85: 141-150

Barcina, I., Ayo, B., Unanue, M., Egea, L. Iriberri, J. (1992). Comparison of rates of flagellates bacterivory and bacterial production in a marine coastal system. Appl. environ. Microbiol. 58: 3850-3856

Bennett, S. J., Sanders, R. W., Porter, K. G. (1990). Heterotrophic, autotrophic, and mixotrophic nanoflagellates: seasonal abundances and bacterivory in a eutrophic lake. Limnol. Oceanogr. 35: 1821-1832

Bloem, J., Bär-Gilissen, M.-J. B. (1989). Bacterial activity and protozoan grazing potential in a stratified lake. Limnol. Oceanogr. 34: 297-309

Bloem, J., Ellenbroek, F. M., Bär-Gilissen, M.-J. B., Cappenberg. T. E. (1989). Protozoan grazing and bacterial production in stratified Lake Vechten estimated with fluorescently labeled bacteria and by thymidine incorporation Appl. environ. Microbiol. 55: 1787-1795

Bratbak, G., Heldal, M., Norland, S., Thingstad, T F. (1990). Viruses as partners in spring bloom microbial trophodynamics. Appl. environ. Microbiol. 56: 1400-1405

Bratbak, G., Heldal, M., Thingstad, T F., Riemann, B., Haslund, O. H. (1992). Incorporation of viruses into the budget of microbial C-transfer A first approach. Mar. Ecol. Prog. Ser. 83: 273-280

Carlough, L. A., Meyer, J. L. (1990). Rates of protozoan bacterivory in three habitats of a southeastern blackwater river. J. N. Am. Benthol. Soc. 9: 45-53

Carlough, L. A., Meyer, J. L. (1991). Bacterivory by sestonic protists in a southeastern blackwater river. Limnol. Oceanogr. 36: 873-883

Caron, D. A., Goldman, J. C., Dennett, M. R. (1986) Effect of temperature on growth, respiration, and nutrient regeneration by an omnivorous microflagellate. Appl environ. Microbiol. 52: 1340-1347 
Caron, D. A., Lim, E. L., Miceli, G., Waterbury, J. B., Valois, F. W. (1991). Grazing and utilization of chroococcoid cyanobacteria and heterotrophic bacteria by protozoa in laboratory cultures and a coastal plankton community. Mar. Ecol. Prog. Ser. 76: 205-217

Choi, J. W., Peters., F. (1992). Effects of temperature on two psychrophilic ecotypes of a heterotrophic nanoflagellate, Paraphysomonas imperforata. Appl environ. Microbiol. 58: $593-599$

Cleveland, W. S. (1979). Robust locally weighted regression and smoothing scatterplots. J. Am. Stat. Ass. 74: 829-836

Coffin, R. B., Sharp, J. H. (1987). Microbial trophodynamics in the Delaware Estuary. Mar. Ecol. Prog. Ser. 41: 253-266

Cole, J. J., Pace, M. L., Caraco, N. F., Steinhart, G. (1993). Bacterial biomass and cell size distribution in lakes: more and larger cells in anoxic waters. Limnol. Oceanogs. (in press)

Coveney, M. F., Wetzel, R. G. (1992). Effects of nutrients on specific growth rate of bacterioplankton in oligotrophic lake water cultures. Appl. environ. Microbiol. 58: 150-156

Curds, C. R., Cockburn, A. (1968). Studies on the growth and feeding of Tetrahymena pyriformis in axenic and monoxenic culture. J. gen. Microbiol. 54: 343-358

Davis, P. G., Sieburth, J. McN. (1984). Estuarine and oceanic microflagellate predation of actively growing bacteria: estimation by frequency of dividing-divided bacteria. Mar. Ecol. Prog. Ser. 19: 237-246

Epstein, S. S., Shiaris, P. (1992). Size-selective grazing of coastal bacterioplankton by natural assemblages of pigmented flagellates colorless flagellates and ciliates. Microb. Ecol. 23: 211-225

Fenchel, T. (1980). Suspension feeding in ciliated protozoa: functional response and particle size selection. Microb. Ecol. 6: 1-12

Fenchel, T. (1982a). Ecology of heterotrophic microflagellates. II. Bioenergetics and growth. Mar. Ecol. Prog. Ser. 8: $225-231$

Fenchel, T. (1982b). Ecology of heterotrophic microflagellates. IV. Quantitative occurrence and importance as bacterial consumers. Mar. Ecol. Prog. Ser. 9: 35-42

Fukami, K., Meier, B., Overbeck, J. (1991). Vertical and temporal changes in bacterial production and its consumption by heterotrophic nanoflagellates in a north German temperate lake. Arch. Hydrobiol. 122: 129-145

Gasol, J. M., Sander, B., Schallenberg, M. (1993). Production of bacteria in freshwater sediments: comparison of different cell-specific measurements to mineralization rates. Verh. int. Verein. Limnol. 25: 325-330

González, J. M., Sherr, E. B., Sherr, B. F. (1990). Size-selective grazing on bacteria by natural assemblages of estuarine flagellates and ciliates. Appl. environ. Microbiol. 56: $583-589$

Güde, H. (1986). Loss processes influencing growth of planktonic bacterial populations in Lake Constance. J. Plankton Res. 8: 795-810

Hagström, $\AA$., Azam, F., Andersson, A., Wikner, J., Rassoulzadegan, F. (1988). Microbial loop in an oligotrophic pelagic marine ecosystem: possible roles of cyanobacteria and nanoflagellates in the organic fluxes. Mar. Ecol. Prog. Ser. 49: 171-178

Jürgens, K. (1992). Is there plenty of food for bacterivorous flagellates in eutrophic waters? Arch. Hydrobiol. Beih. Ergebn. Limnol. 37: 195-205

King, K. R., Hollibaugh J. T., Azam, F. (1980). Predator-prey interactions between the larvacean Oikopleura dioica and bacterioplankton in enclosed water columns. Mar. Biol. 56: $49-57$
Kirchman, D. L. (1990). Limitation of bacterial growth by dissolved organic matter in the subartic Pacific. Mar. Ecol. Prog. Ser. 62: 47-54

Kuuppo-Leinikki, P., Kuosa, H. (1990). Estimation of flagellate grazing on bacteria by size fractionation in the Northern Baltic Sea. Arch. Hydrobiol. Beih. 34: 283-292

Landry, M. R., Haas, L. W., Fagerness, V. L. (1984). Dynamics of microbial plankton communities: experiments in Kaneohe Bay, Hawaii. Mar. Ecol. Prog. Ser. 16: 127-133

Landry, M. R., Lehner-Fournier, J. M., Sundstrom, J. A., Fagerness, V. L., Selph, K. E. (1991). Discrimination between living and heat-killed prey by a marine zooflagellate, Paraphysomonas vestita (Stokes), J. exp. mar. Biol. Ecol. 146: 139-151

Marrasé, C., Lim, E. L., Caron, D. A. (1992). Seasonal and daily changes in bacterivory in a coastal plankton community. Mar. Ecol. Prog. Ser. 82: 281-289

McManus, G. B., Fuhrman, J. A. (1988). Clearance rates of bacteria-sized particles by natural populations of nanoplankton in the Chesapeake Bay outflow plume. Mar. Ecol. Prog. Ser. 42: 199-206

McManus, G. B., Okubo, A. (1991). On the use of surrogate food particles to measure protistan ingestion. Limnol. Oceanogr. 36: 613-617

Moloney, C. L., Field, J. G. (1989). General allometric equations for rates of nutrient uptake, ingestion and respiration in plankton organisms. Limnol. Oceanogr. 34: 1290-1299

Morris, D. P., Lewis, W. M. Jr (1992). Nutrient limitation of bacterioplankton growth in Lake Dillon, Colorado. Limnol. Oceanogr. 37: 1179-1192

Nygaard, K., Hessen, D. O. (1990). Use of ${ }^{14} \mathrm{C}$-protein-labelled bacteria for estimating clearance rates by heterotrophic and mixotrophic flagellates. Mar. Ecol. Prog. Ser. 68: 7-14

Pace, M. L., Bailiff, M. D. (1987). Evaluation of a fluorescent microsphere technique for measuring grazing rates of phagotrophic microorganisms. Mar. Ecol. Prog. Ser. 40: 185-193

Pace, M. L. (1988). Bacterial mortality and the fate of bacterial production. Hydrobiology 159: 41-49

Pace, M. L., McManus, G. B., Findlay, S. E. G. (1990). Planktonic community structure determines the fate of bacterial production in a temperate lake. Limnol. Oceanogr. 35: 795-808

Pedrós-Alió, C., Brock, T. D. (1983). The impact of zooplankton feeding on the epilimnetic bacteria of a eutrophic lake. Freshwat, Biol. 13: 227-239

Peters, F. (1994). The prediction of planktonic protistan grazing rates. Limnol. Oceanogr. 39: 195-205

Rosenberg, R., Dahl, E., Edler, L., Fryberg, L., Granéli, E., Granéli, W., Hagström, A., Lindahl, O., Matos, M. O., Pettersson, K., Sahlsten, E., Tiselius, P., Turk, V., Wikner, J. (1990). Pelagic nutrient and energy transfer during spring in the open and coastal Skagerrak. Mar. Ecol. Prog. Ser. 61: $215-231$

Sanders, R. W. Porter, K. G. (1986). Use of metabolic inhibitors to estimate protozooplankton grazing and bacterial production in a monomictic eutrophic lake with an anaerobic hypolimnion. Appl. environ. Microbiol. 52: $101-107$

Sanders, R. W., Porter, K. G., Bennett, S. J., DeBiase, A. E. (1989). Seasonal patterns of bacterivory by flagellates, ciliates, rotifers, and cladocerans in a freshwater planktonic community. Limnol. Oceanogr. 34:673-687

Sanders, R. W., Caron, D. A., Berninger U.-G. (1992). Relationships between bacteria and heterotrophic nanoplankton in marine and fresh waters: an inter-ecosystem comparison. Mar. Ecol. Prog. Ser. 86: 1-14 
Scavia, D., Laird, G. A. (1987). Bacterioplankton in Lake Michigan: dynamics, controls, and significance to carbon flux. Limnol. Oceanogr. 32: 1017-1033

Sherr, B. F., Sherr, E. B., Newell, S. Y. (1984). Abundance and productivity of heterotrophic nanoplankton in Georgia coastal waters. J. Plankton Res. 6: 195-202

Sherr, B. F., Sherr, E. B., Andrew, T. L., Fallon, R. D., Newell, S. $Y$. (1986). Trophic interactions between heterotrophic protozoa and bacterioplankton in estuarine water analyzed with selective metabolic inhibitors. Mar. Ecol. Prog. Ser. 32: 169-179

Sherr, B. F., Sherr, E. B., Fallon, R. D. (1987). Use of monodispersed, fluorescently labeled bacteria to estimate in situ pro protozoan bacterivory. Appl. environ. Microbiol. 53: 958-965

Sherr, B. F., Sherr, E. B., Pedrós-Alió, C. (1989). Simultaneous measurement of bacterioplankton production and protozoan bacterivory in estuarine water. Mar. Ecol. Prog. Ser: 54. 209-219

Sieracki, M. E., Haas, L. W., Caron, D. A., Lessard, E. J. (1987). Effect of fixation on particle retention by microflagellates: underestimation of grazing rates. Mar. Ecol. Prog. Ser. 38: 251-258

Simek, K., Macek, M., Vyhnálek, V. (1990a). Uptake of bacteria-sized fluorescent particles by natural protozoan assemblage in a reservoir. Arch. Hydrobiol. Beih. Ergebn. Limnol. 34: 275-281

Simek, K., Macek, M., Sedâ, J., Vyhnálek, V. (1990b). Possible food chain relationships between bacterioplankton, protozoans, and cladocerans in a reservoir. Int. Rev. ges. Hydrobiol. 75: 583-596

Simek, K., Straskrabová, V. (1992). Bacterioplankton production and protozoan bacterivory in a mesotrophic reservoir. J. Plankton Res. 14: 773-787

Simek, K., Chrzanowski, T. H. (1992). Direct and indirect evidence of size-selective grazing on pelagic bacteria by freshwater nanoflagellates. Appl. environ. Microbiol. 58: $3715-3720$

Taylor, R. J. (1984). Predation, population and community biology series. Chapman and Hall, New York

Taylor, G. T., Pace, M. L. (1987). Validity of eukaryotic inhibitors for assessing production and grazing mortality of marine bacterioplankton. Appl. environ. Microbiol. 53: 119-128

This article was submitted to the editor
Tobiesen, A. (1990). Temperature dependent filtration rates and size selection in some heterotrophic microflagellates and one dinoflagellate. Arch. Hydrobiol. Beih. Ergebn Limnol. 34: 293-304

Toolan, T., Wehr, J. D., Findlay, S. (1991). Inorganic phosphorus stimulation of bacterioplankton production in a meso-eutrophic lake. Appl. environ. Microbiol. 57: $2074-2078$

Turner, J. T., Tester, P. A., Ferguson, R. L. (1988). The marine cladoceran Penilia avirostris and the microbial loop of pelagic food webs. Limnol. Oceanogr. 33: 245-255

Vaqué, D., Pace, M. L. (1992). Grazing on bacteria by flagellates and cladocerans in lakes of contrasting food-web structure. J. Plankton Res. 14: 307-321

Vaqué, D., Pace, M. L., Findlay, S. E. G., Lints, D. (1992). Fate of bacterial production in a heterotrophic ecosystem: grazing by protists and metazoans in the Hudson estuary. Mar. Ecol. Prog. Ser. 89: 155-163

Weisse, T. (1989). The microbial loop in the Read Sea: dynamics of pelagic bacteria and heterotrophic nanoflagellates. Mar. Ecol. Prog. Ser. 55: 241-250

Weisse, T. (1990). Trophic interactions among heterotrophic microplankton, nanoplankton and bacteria in Lake Constance. Hydrobiology 191: 111-122

Weisse, T. (1991). The microbial food web and its sensitivity to eutrophication and contaminant enrichment: a cross-system overview. Int. Revue ges. Hydrobiol. 76: 327-337

Wiebe, W. J., Sheldon, W. M. Jr, Pomeroy, L. R. (1992). Bacterial growth in the cold: evidence for an enhanced substrate requirement. Appl. environ. Microbiol. 58: 359-364

White, P. A., Kalff, J., Rasmussen, J. B., Gasol, J. M. (1991). The effect of temperature and algal biomass on bacterial production and specific growth rate in freshwater and marine habitats. Microb. Ecol. 21: 99-118

Wikner, J., Andersson, A., Normark, S., Hagström, A. (1986). Use of genetically marked minicells as a probe in measurement of predation on bacteria in aquatic environments. Appl, environ. Microbiol. 52: 4-8

Wikner, J., Rassoulzadegan, F., Hagström, $\AA$. (1990). Periodic bacterivore activity balances bacterial growth in the marine environment. Limnol. Oceanogr. 35: 313-324

Wilkinson, L. (1989). SYSTAT: the system for statistics. SYSTAT, Inc., Evanston, IL

Manuscript first received: September 7, 1993

Revised version accepted: April 5, 1994 